\title{
Changing Coal Mining Brownfields into Green Infrastructure Based on Ecological Potential Assessment in Xuzhou, Eastern China
}

\author{
Shanshan Feng ${ }^{1,2}$, Wei Hou ${ }^{3}$ and Jiang Chang ${ }^{1, *}$ \\ 1 School of Architecture and Design, China University of Mining and Technology, Xuzhou 221116, China; \\ fengshanshan@cumt.edu.cn \\ 2 Jiangsu Vocational Institute of Architectural Technology, Xuzhou 221008, China \\ 3 Chinese Academy of Surveying and Mapping, Beijing 100830, China; houwei@casm.ac.cn \\ * Correspondence: changiiang102@163.com
}

Received: 19 March 2019; Accepted: 11 April 2019; Published: 15 April 2019

\begin{abstract}
It is widely recognized that brownfield regeneration to green space is a sustainable form of urban development. However, it is essential to choose those brownfields that have the greatest potential to be integrated into urban green infrastructure (GI). This paper addresses how to quantitatively assess the ecological potential of coal mining brownfields at the city level, and looks at how these brownfields can be best adapted to enhance the GI system. Taking Xuzhou as an example, an ecological potential assessment method for brownfield regeneration to green space is established considering both its ecological importance and the capacity of maintaining GI connectivity. The results show that more than half of the coal mining brownfields have relatively higher ecological importance values, and only four patches play an important role in maintaining GI connectivity. The final ecological potential values of brownfield regeneration to green space are obtained by overlaying the values of ecological importance and the capacity values of maintaining GI connectivity. Then, all the brownfields are divided into five groups according to their ecological potential values, which are significantly different in each group. Around $51.35 \%$ of the brownfields have a high or very high potential for restoration to GI, which are distributed in the southeastern part of the western mining area and the central part of the eastern mining area. The presented method can assist reclamation scientists and urban planners in decision making based on quantitative analysis.
\end{abstract}

Keywords: mining brownfield; green infrastructure; coal mining city; brownfield greening; landscape connectivity; sustainable development

\section{Introduction}

China's coal production and consumption are among the highest in the world [1]. The intensive extraction of coal leads to large areas of coal mining brownfields. A coal mining brownfield refers to the land damaged, collapsed, occupied, or underutilized due to open-pit or underground mining, not only including abandoned mining operation systems, but also mining subsidence land and coal waste piles [2]. Coal mining brownfields are often viewed as a serious problem in resource-based cities [3], as they are associated with landscape fragmentation, economic degradation, and social conflict. Especially in eastern China, the underground coal mining caused a large proportion of subsided mining brownfields, which were accompanied by water accumulation [4]. Therefore, the mining brownfield regeneration is of significance to urban sustainable development. In most cases, these mining brownfields will be converted into construction land or reclaimed for agricultural land by deep-digging and shallow-filling [5]. However, the coal mining brownfield in eastern China is also thought to hold huge potential for greening the city due to its large areas of subsidence water [6]. 
In practice, urban wetland parks are regarded as one of the most common forms of coal mining brownfield greening. Such regeneration processes have been branded as a sustainable approach to urban land use [7]. It has been demonstrated that converting coal mining brownfields into urban green spaces can contribute to the enhancement of urban green infrastructure (GI), providing ecosystem services and supporting the health and well-being of the population [8-10].

A substantial amount of research has been conducted into linking brownfield and urban greenspace [11-13], and this has tended to concentrate on benefits, monitoring and evaluating the outcome of brownfield greening projects [14-17], as well as the planning process [18], the incentives, and the barriers regarding conversion from brownfield to greenspace [19]. However, the identification of brownfields for greenspace space regeneration has often been somewhat arbitrary, as this is usually determined by the will of the central government. There is less concerned on how to select those brownfields with the highest potential to be changed into greenspace in the total urban area. Some researchers put forward the assessment method of brownfield greening, but there is still a lack of a holistic view or quantitative analysis. For example, Altherr suggested that the distance to the city center, the involvement of the stakeholders, and the current legislation are important in determining the greening project location [20]. Mathey selected different types of urban brownfield samples to identify their potential for conversion in the GI system by creatively evaluating their ecosystem service function [21], although here he focused only on the ecological status of the land itself. Further research is needed in order to quantitatively assess the comprehensive potential of brownfield greening in an overall urban landscape context.

Green infrastructure (GI) refers to a continuous network of greenspace composed of patches, corridors, and stepping stones to support the natural ecosystems and bring benefits to human beings [22]. Changing brownfield to greenspace essentially means integrating brownfield into the GI network. The ecological potential of brownfield greening is not only determined by the ecological suitability and importance, but also by its position in GI networks [23]. Some brownfields in or close to key patches or corridors have special significance for improving the ecological structure and functions of GI [24]. The aim of this research is to explore how to assess the ecological potential of brownfield converted into GI in order to inform the planning and decision-making processes surrounding coal mining brownfields. An evaluation index system should be established considering both ecological status on site and the surrounding human activities, even the structure of GI. Taking Xuzhou City as an example, we finally identified the restoration priority of brownfields to be integrated into GI by assessing the ecological potential of each brownfield. For enhancing the connectivity and stability of GI, the ecological potential of coal mining brownfields is assessed from two aspects: the ecological importance of mining brownfields and the ability to maintain GI connectivity. At last, the brownfields that have relatively higher ecological potential are identified and ranked. Then, the suggestions about the land-use planning of coal mining brownfields and urban GI structure are put forward.

\section{Coal Mining Brownfield in Xuzhou, Eastern China}

Eastern China is an economically well-developed region, where the earliest large-scale industrial coal mines are located. After more than 50 years of coal mining, this region is on the verge of resource exhaustion [1]. Many cities have been built around the mines in this region, which has led to a large number of mining brownfields located in or at the edge of the urban area [25]. Xuzhou is located in the northwest of Jiangsu Province, southeast of the North China Plain. The landscape within and around the city is dominated by fluvial plains and hills, which account for $90.6 \%$ and $9.4 \%$ of the total land, respectively. The Huai River and the Old Yellow River as well as the Beijing-Hangzhou Grand Canal cut through the urban area. Xuzhou is rich in mineral resources and used to be an important coal production base for China. Our research is limited to the metropolitan urban area of Xuzhou, covering an area of $3126 \mathrm{~km}^{2}$. The forest is mainly distributed in the surrounding mountain area. The GI includes main mountains and water within the urban area, with a typical wedge structure in Xuzhou. GI sources refer to large natural patches, and are the source of various ecological processes, 
providing habitat or migration destinations for wildlife. In this paper, GI sources include large natural reserves, scenic spots, and large urban parks in Xuzhou (Figure 1).
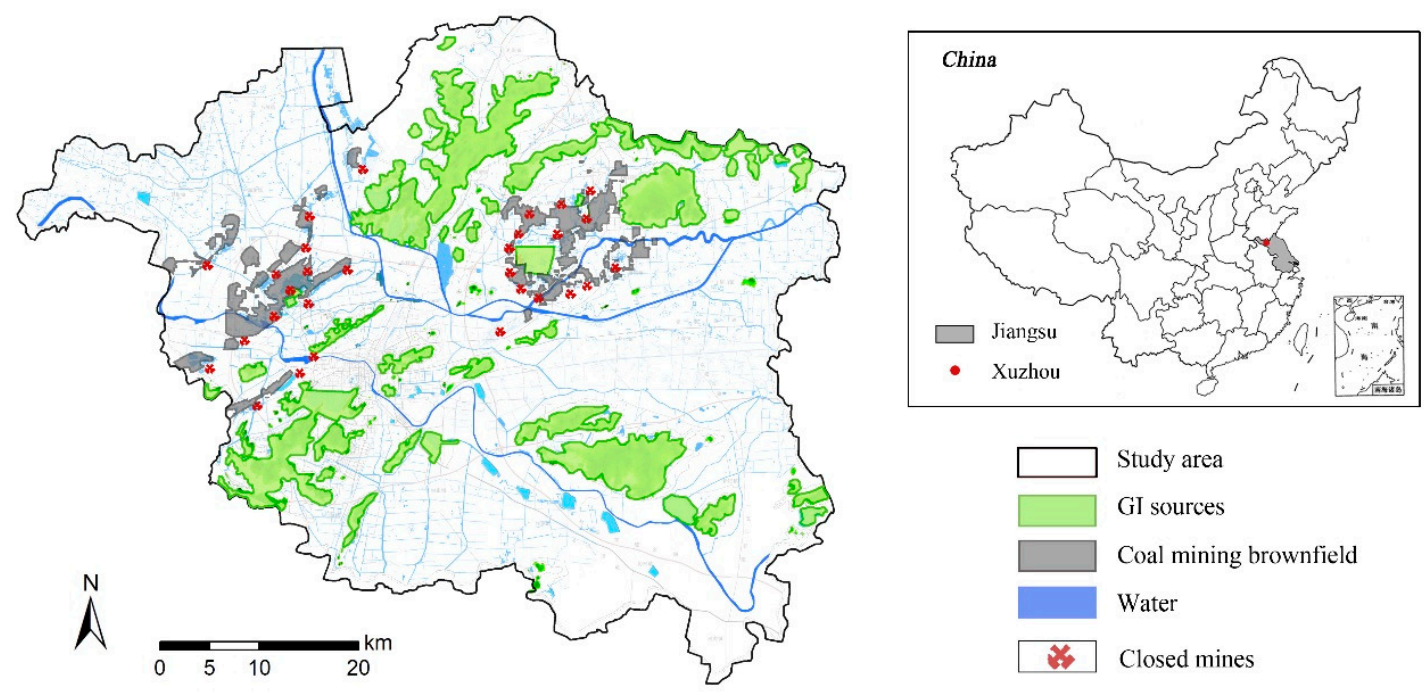

Figure 1. Location and description of the study area.

There used to be 29 coal mines in the area (Figure 1), which were gradually closed by 2012 due to resource exhaustion [26]. As a result, a large number of mining brownfields emerged, including large-scale subsided areas, waste dumps, and industrial squares (Figure 2). They are distributed in the urban fringe where ecological and social environments are fragile [27]. The mining brownfields, which were mostly concentrated in the east and west of the study area, had an area of $1.08 \times 10^{8} \mathrm{~m}^{2}$, and the subsided mining brownfields were close to $0.7 \times 10^{8} \mathrm{~m}^{2}$ by 2015. A large fraction of these are still not stable at present. Some brownfields with small subsidence depth were reclaimed as cultivated land. Some closed mines were reused as aquaculture areas and wetland parks, with new ecosystems formed by self-recovery and manual intervention. Although changing mining brownfields to urban parks can enhance biodiversity and urban ecosystem services [28,29], and plays an important role in improving the GI structure in Xuzhou, there has been a degree of randomness in selecting the mining brownfields that have been regenerated to GI. It is necessary to identify those mining brownfields with high ecological potential before recovering them to urban green spaces.

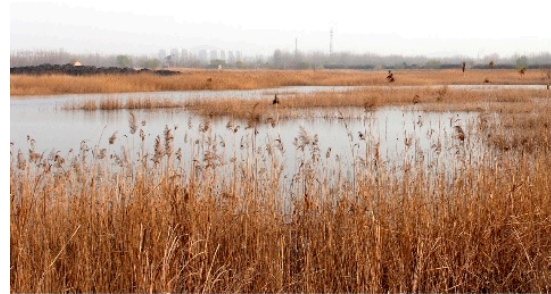

(a)

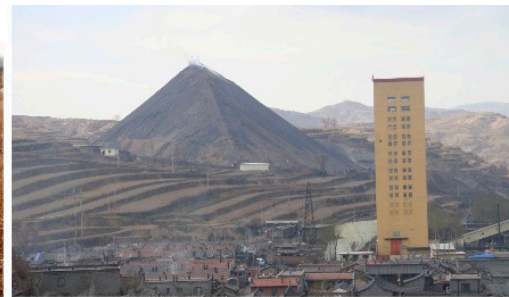

(b)

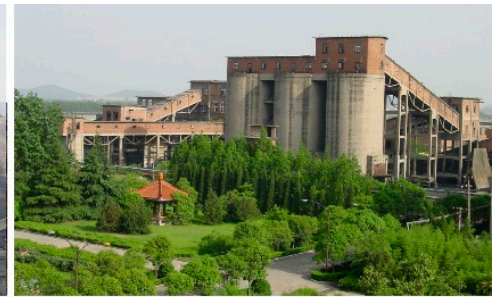

(c)

Figure 2. Different types of coal mining brownfields in Xuzhou. (a) Subsided land; (b) waste dump; (c) industrial square.

\section{Methodology}

The key of the study is to establish an ecological potential assessment method. Firstly, data was collected and analyzed for identifying the range of coal mining brownfields and GI sources. Then, two indicators describing the ecological importance $(E I)$ and GI connectivity $(d P C)$ of mining brownfields were assessed respectively at the local scale and urban scale, and the value of ecological potential (Pgi) was obtained by overlaying these two indicators. We selected the coal mining brownfields 
with relatively high and very high Pgi values to integrate into the GI system. At last, a GI structure framework was proposed based on the results (Figure 3).

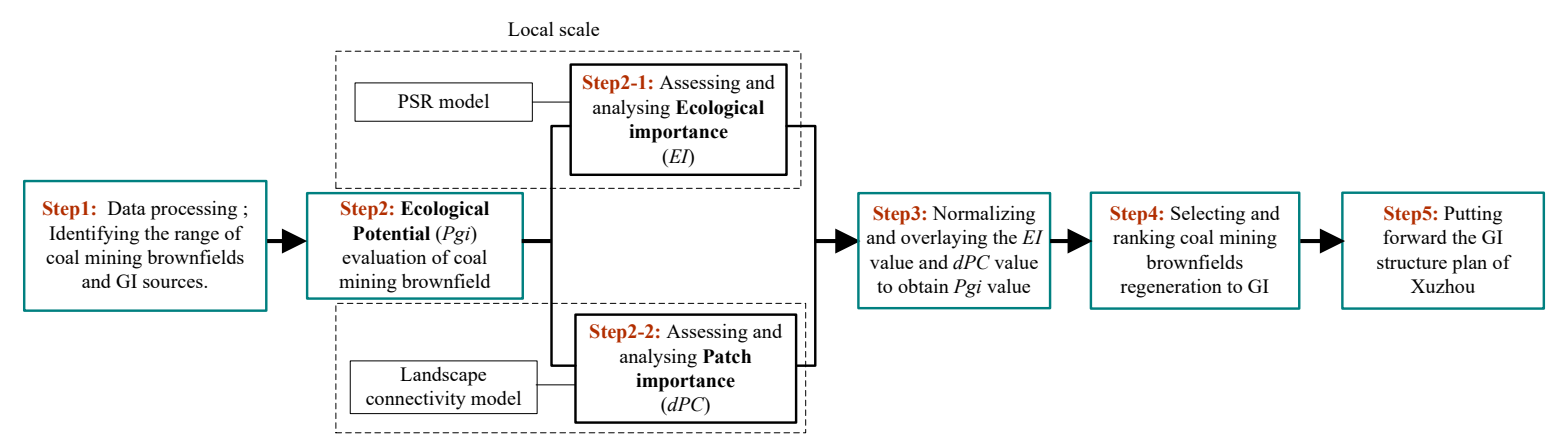

Figure 3. Methodological diagram.

\subsection{Data Sources}

Based on the Landsat-TM remote sensing image (spatial resolution $30 \mathrm{~m}$ ) of Xuzhou City in June 2015, we divided land cover into five categories by human-computer interaction on the ENVI (The Environment for Visualizing Images) platform: water, forest, cultivated land, grassland, and built-up land (Figure 4). The interpretation result was modified by checking Google Earth high-precision images and a typical field survey. Then, we further produced the Normalized Difference Vegetation Index (NDVI) of Xuzhou. Combining the land-cover type map with the NDVI map, the important patches of GI sources in Xuzhou were obtained. Referring to the previous results of the GI network research [30], the criteria used for GI sources selection included: (1) most of the urban important ecological protection area; (2) an area greater than $0.5 \times 10^{6} \mathrm{~m}^{2}$; and (3) an NDVI greater than 0.3 . The total area of GI source patches is nearly $3.03 \times 10^{8} \mathrm{~m}^{2}$. The border of the mining brownfields was identified based on the distribution map of coal mining subsidence in Xuzhou City (2015), referring to the Special Plan for Adjustment and Utilization of Industrial Wasteland Reclamation in Xuzhou (2012-2015). Those mining brownfields in the study area were divided into two concentrated areas: the eastern mining area and the western mining area, with a total area of about $1.08 \times 10^{8} \mathrm{~m}^{2}$, accounting for $3.5 \%$ of the study area.

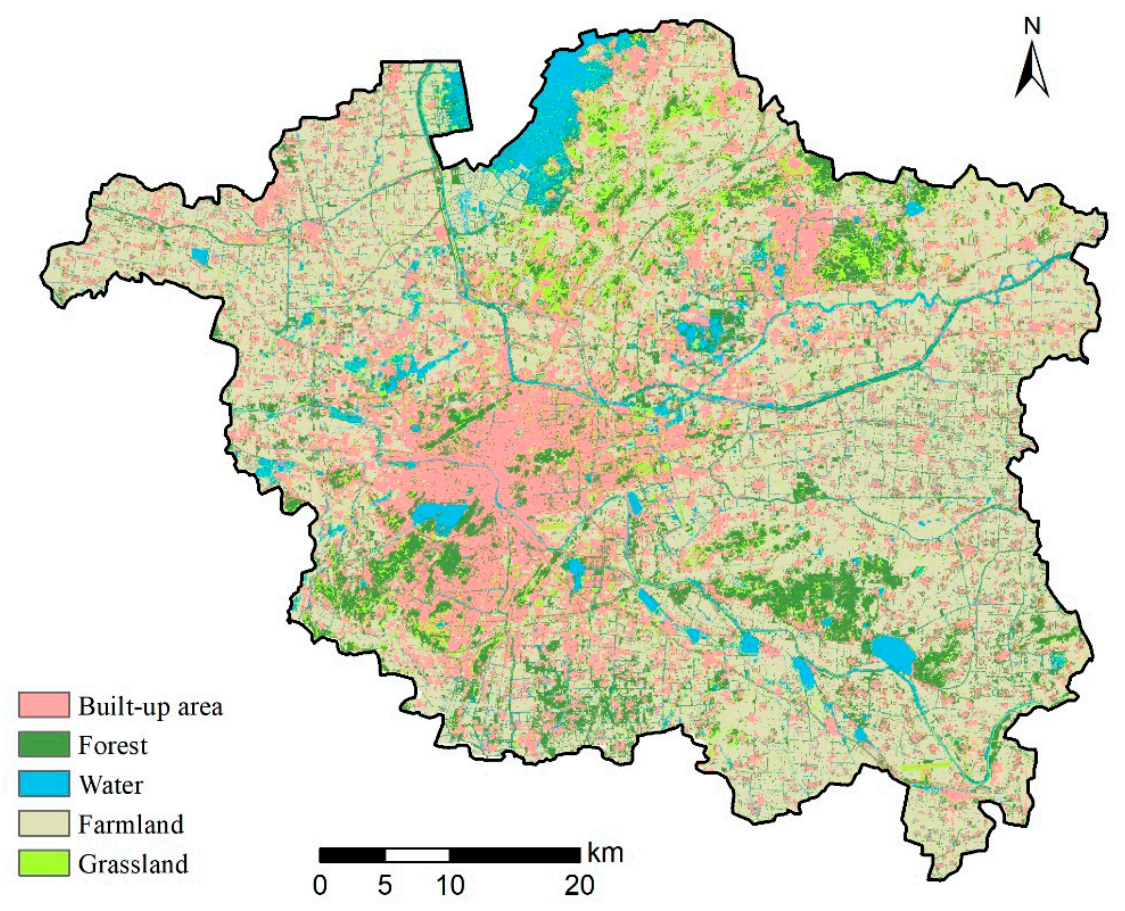

Figure 4. Land cover map of Xuzhou. 


\subsection{Analytical Method}

There are two important factors in determining the ecological potential of mining brownfield regeneration to GI (Pgi). (1) The first is the suitability of mining brownfield itself as GI. Ecological importance (EI) is used to characterize the degree of GI suitability, which reflects the ecological status of the coal mining brownfield, and the suitability and limitation of GI. (2) The second factor is the importance of maintaining GI network connectivity. The patch importance $(d P C)$ is applied to reflect the ability of the patch to maintain an ecological flow in the substrate landscape [31].

Both factors have equally important influences on judging the ecological potential of mining brownfields regenerated to GI. Therefore, the $E I$ value and the $d P C$ value were finally normalized and added to obtain the Pgi value.

$$
P g i=\sum_{i=1}^{n} W_{i} X_{i}
$$

In the formula, $X_{i}$ is the score of the $E I$ and $d P C$, while $W_{i}$ is the weight of each indicator.

\section{(1). Ecological importance (EI)}

Ecological importance refers to the potential of maintaining an urban ecological balance and preventing ecological deterioration or degradation [32]. In this study, we adopted the "Pressure-StateResponse (PSR)" framework, which is often used to reflect the interaction between human beings and the environment, in order to establish the ecological importance index system by considering both the impacts of human disturbances and protections on the ecological state of brownfields. The index system includes eight indicators (Figure 5). Specifically, the " $P$ " index represents the external pressure on the land system [33], including land-use type (P1), distance from major traffic routes (P2), distance from critical infrastructure (P3), and distance from pollution sources $(P 4)$. Among them, $P 2, P 3$, and $P 4$ are reverse indicators, reflecting the degree of human interference in mining sites. The " $S$ " index represents the change of natural resources, including NDVI (S1) and distance from rivers and lakes (S2). The " $R$ " index represents human protective measures to improve adverse effects, including distance from historical and cultural heritage $(R 1)$ and distance from ecological protection red lines $(R 2)$.

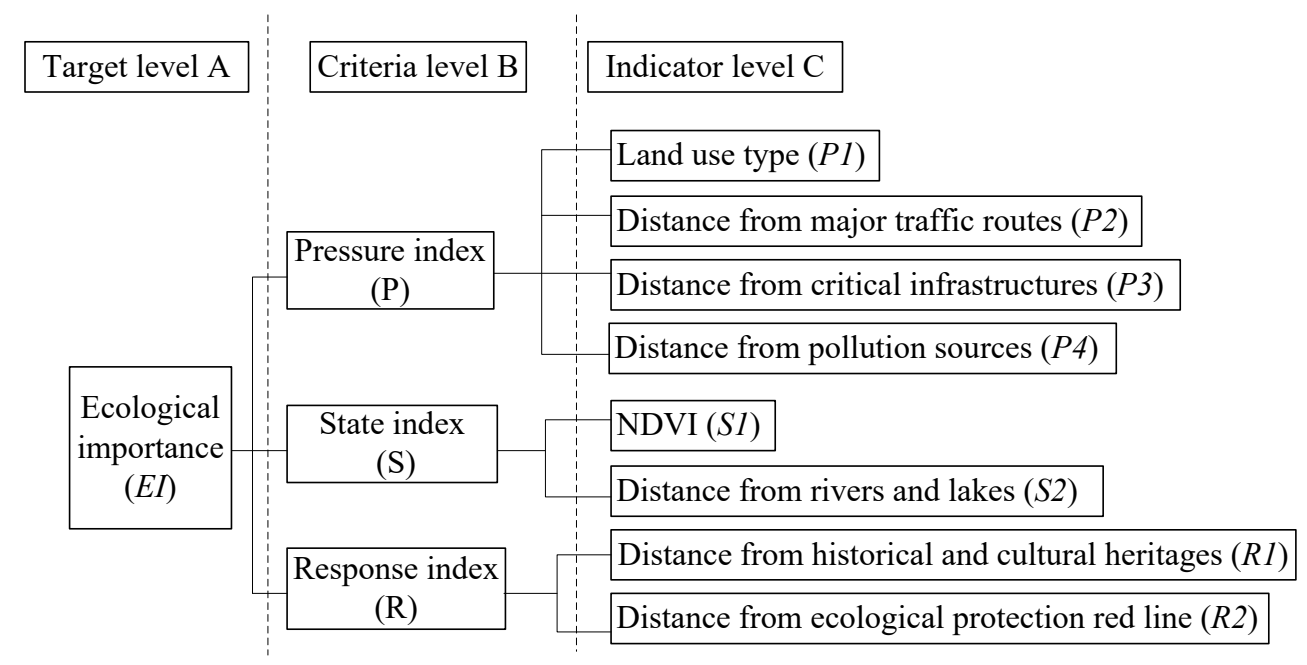

Figure 5. Index system of ecological importance $(E I)$ evaluation of coal mining brownfield.

The classification of the indicators can be found in Table 1. Each indicator is set in a scale, where one means the lowest value, and five means the highest (Table 1). All the indicators were created on a $30 \times 30 \mathrm{~m}$ grid map. The final ecological importance value of the mining brownfield is actually a weighted accumulation of indicator maps that can be obtained by spatially overlaying all the indicator maps in the environment of ArcGIS 10.2. The weights used in this research are shown in Table 2, which are calculated by using the analytic hierarchy method. 
Table 1. Index criteria of EI evaluation of coal mining brownfield. NDVI: Normalized Difference Vegetation Index.

\begin{tabular}{|c|c|c|c|c|c|}
\hline Index & Indicator & \multicolumn{2}{|c|}{ Class Condition } & Value & References \\
\hline \multirow{17}{*}{$\begin{array}{l}\text { Pressure } \\
\text { Index }\end{array}$} & \multirow{5}{*}{$\begin{array}{l}\text { Land-use type } \\
\qquad(P 1)\end{array}$} & \multicolumn{2}{|c|}{ Forest } & 5 & \multirow{5}{*}{$\begin{array}{l}\text { According to the weight of each habitat type that characterizes the habitat quality index in the } \\
\text { "Technical Specifications for Ecological Environment Assessment" (HJ192-2015), forest has the } \\
\text { highest value, and construction land has the lowest value [34]. }\end{array}$} \\
\hline & & \multicolumn{2}{|c|}{ Water } & 4 & \\
\hline & & \multicolumn{2}{|c|}{ Grassland } & 3 & \\
\hline & & \multicolumn{2}{|c|}{ Cultivated land } & 2 & \\
\hline & & \multicolumn{2}{|c|}{ Construction land } & 1 & \\
\hline & \multirow{5}{*}{$\begin{array}{l}\text { Distance from major traffic routes } \\
\qquad(P 2)\end{array}$} & \multicolumn{2}{|c|}{ Buffer larger than $1000 \mathrm{~m}$} & 5 & \multirow{5}{*}{ [32] } \\
\hline & & \multicolumn{2}{|c|}{$500-1000 \mathrm{~m}$ buffer } & 4 & \\
\hline & & \multicolumn{2}{|c|}{$200-500 \mathrm{~m}$ buffer } & 3 & \\
\hline & & \multicolumn{2}{|c|}{ 100-200 m buffer } & 2 & \\
\hline & & \multicolumn{2}{|c|}{ 0-100 m buffer } & 1 & \\
\hline & \multirow{3}{*}{$\begin{array}{l}\text { Distance from critical infrastructures } \\
\qquad(P 3)\end{array}$} & \multicolumn{2}{|c|}{ Buffer larger than $75 \mathrm{~m}$} & 5 & \multirow{3}{*}{$\begin{array}{l}\text { Referring to the "power project status map of Xuzhou" (2014), power plants and high-pressure } \\
\text { lines above 500 kv were selected. According to the "Urban Electric Power Planning Code" } \\
\text { (GB/T 50293-2014), buffer division of high-pressure corridors were defined [35]. }\end{array}$} \\
\hline & & \multicolumn{2}{|c|}{ 40-75 m buffer } & 3 & \\
\hline & & \multicolumn{2}{|c|}{ 0-40m buffer } & 1 & \\
\hline & \multirow{4}{*}{$\begin{array}{l}\text { Distance from pollution sources } \\
\qquad(P 4)\end{array}$} & \multicolumn{2}{|c|}{ Buffer larger than $800 \mathrm{~m}$} & 5 & \\
\hline & & \multicolumn{2}{|c|}{$500-800 \mathrm{~m}$ buffer } & 3 & According to the "environmental protection and sanitation status map of Xuzhou"(2014), \\
\hline & & \multicolumn{2}{|c|}{$300-500 \mathrm{~m}$ buffer } & 2 & $\begin{array}{c}\text { pollution sources include industrial land (I class), coal gangue dump, landfill, sewage } \\
\text { treatment plant }[36] \text {. }\end{array}$ \\
\hline & & \multicolumn{2}{|c|}{ 0-300 m buffer } & 1 & \\
\hline & & \multicolumn{2}{|c|}{$0.6<\mathrm{NDVI}<1$} & 5 & \\
\hline & NDVI & & $\mathrm{NDVI}<0.6$ & 4 & [32] \\
\hline & & & $\mathrm{NDVI}<0.4$ & 3 & \\
\hline & & & $\mathrm{DVI}<0.2$ & 2 & \\
\hline & & & $0-500 \mathrm{~m}$ buffer & 5 & \\
\hline StateIndex & & 1st order stream & 500-1000 m buffer & 3 & \\
\hline & Distance from rivers and lakes & & $1000-2000 \mathrm{~m}$ buffer & 2 & {$[32.37]$} \\
\hline & $(S 2)$ & & Buffer larger than $2000 \mathrm{~m}$ & 1 & $[32,3]]$ \\
\hline & & 2nd order stream & 0-100 m buffer & 3 & \\
\hline & & & Buffer larger than $100 \mathrm{~m}$ & 1 & \\
\hline & & Lake & $0-500 \mathrm{~m}$ buffer & 3 & \\
\hline & & & Buffer larger than $500 \mathrm{~m}$ & 1 & \\
\hline & Distance from historical and cultural & & m buffer & 5 & \\
\hline & $\begin{array}{l}\text { heritages } \\
(R 1)\end{array}$ & & $0 \mathrm{~m}$ buffer & 3 & [38] \\
\hline & & Buffer 1 & ger than $500 \mathrm{~m}$ & 1 & \\
\hline & & & e red line & 5 & \\
\hline ResponseIndex & $\begin{array}{l}\text { Distance from ecological protection red } \\
\text { line }\end{array}$ & & m buffer & 4 & Referring to the "Ecological Red Line Regional Protection Plan of liangsu Province" (2013), the \\
\hline & & & $0 \mathrm{~m}$ buffer & 3 & 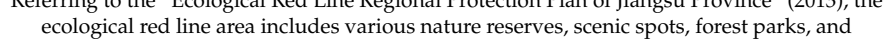 \\
\hline & & & 000 buffer & 2 & important water conservation areas. Buffer division standard referenced literature [39]. \\
\hline & & Buffer lic & er than $1000 \mathrm{~m}$ & 1 & \\
\hline
\end{tabular}


Table 2. Indicator weights of EI evaluation.

\begin{tabular}{ccccc}
\hline Criteria & Criteria Weight & Indicator & Indicator Weight & Sequence \\
\hline \multirow{2}{*}{ Pressure index (P) } & \multirow{2}{*}{0.4934} & $P 1$ & 0.2951 & 1 \\
\cline { 3 - 4 } & & $P 2$ & 0.0525 & 7 \\
\cline { 3 - 4 } & & $P 3$ & 0.0525 & 7 \\
\hline \multirow{2}{*}{ State index (S) } & \multirow{2}{*}{0.3108} & $S 1$ & 0.0933 & 5 \\
\hline \multirow{2}{*}{ Response index (R) } & \multirow{2}{*}{0.1958} & $S 2$ & 0.2072 & 2 \\
\cline { 3 - 4 } & & $R 1$ & 0.1036 & 4 \\
\hline
\end{tabular}

\section{(2). Patch importance $(d P C)$}

The location of the mining brownfield in the GI network as well as its impact on landscape ecological processes is also an important factor for determining its suitability and potential as GI. In this study, mining brownfields were considered as potential GI in the evaluation of GI connectivity.

The change of GI connectivity with and without the integration of a mining brownfield into GI can reflect the importance of each mining brownfield patch in maintaining the connectivity of the GI network. The possible connectivity index $(P C)$ was used to characterize the GI connectivity, and the patch importance of each mining brownfield to maintain the GI connectivity was calculated as follows [40]:

$$
\begin{gathered}
\operatorname{dPC}(\%)=100 \times \frac{P C a d d-P C}{P C} \\
P C=\frac{\sum_{i=0}^{n} \sum_{j=0}^{n} a_{i} \cdot a_{j} \cdot P_{\mathrm{i} j}^{*}}{A_{L}^{2}}
\end{gathered}
$$

where $P C$ represents the connectivity index value of all the GI patches, $P C_{a d d}$ is the connectivity index value of the total patches after adding one coal mining brownfield patch, $n$ represents the total number of patches, $a_{i}$ and $a_{j}$ represent the areas of patch $\mathrm{i}$ and patch $\mathrm{j}, A_{L}$ represents the total area of the study area, and $P^{*} i$ is the probability of species directly spreading between patch $i$ and patch $j$. According to the research area, patch distribution pattern, and existing research results [41], $10 \mathrm{~km}$ was selected as the threshold of patch connectivity.

The larger the $d P C$, the higher the patch importance, which means the stronger ability of the patch to maintain landscape connectivity, and its greater suitable for conversion from brownfield to GI.

\section{Results}

\subsection{Ecological Importance Value (EI)}

In this study, 42 GI source patches and 147 mining brownfield patches were identified. The evaluation results of each indicator were calculated (Figure 6), and the EI value of the coal mining brownfields are shown in Figure 7. It can be seen that the EI ranges between 1.21-4.82, which means that the suitability of coal mining brownfield conversion to GI are quite different for the different areas. The coal mining brownfield area with $E I$ values greater than three is about $0.36 \times 10^{8} \mathrm{~m}^{2}$, accounting for $34.15 \%$ of the total area of mining brownfield, and these brownfield patches have higher importance and potential for conversion to GI. Meanwhile, the area of the mining brownfield with EI values between $2-3$ accounts for $54.17 \%$ of the total, which indicates that more than half of the mining brownfields have some ecological potential to be integrated into GI. Generally, the brownfields with relative high EI values have at least one of the following characteristics: they are in the buffer zones of an important ecological protection area; they are in the basins of urban important rivers; they 
are far from important infrastructures such as transportation and power plants; they have high plant coverage; or they are far away from pollution sources.

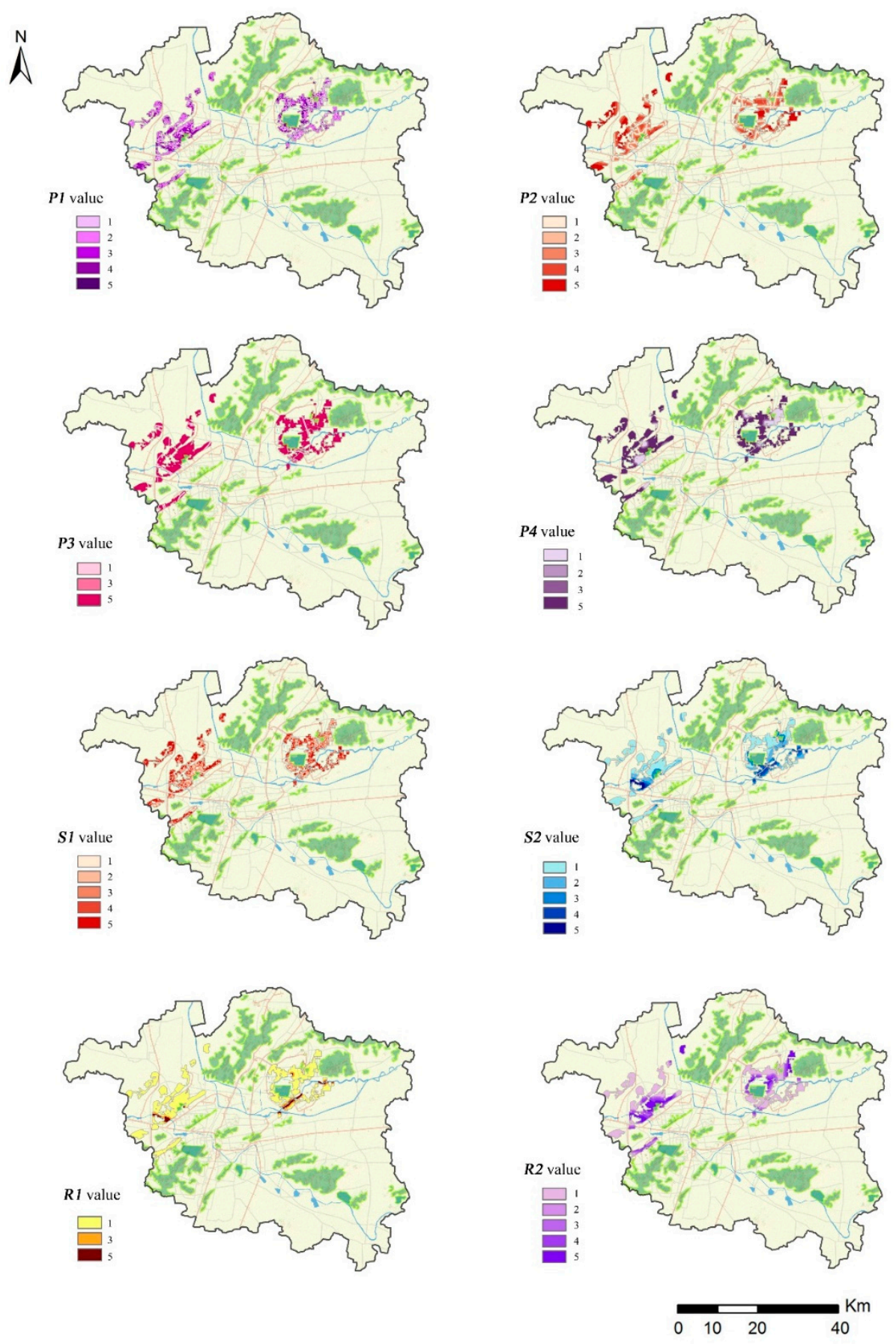

Figure 6. Each index result for EI evaluation of mining brownfields. 


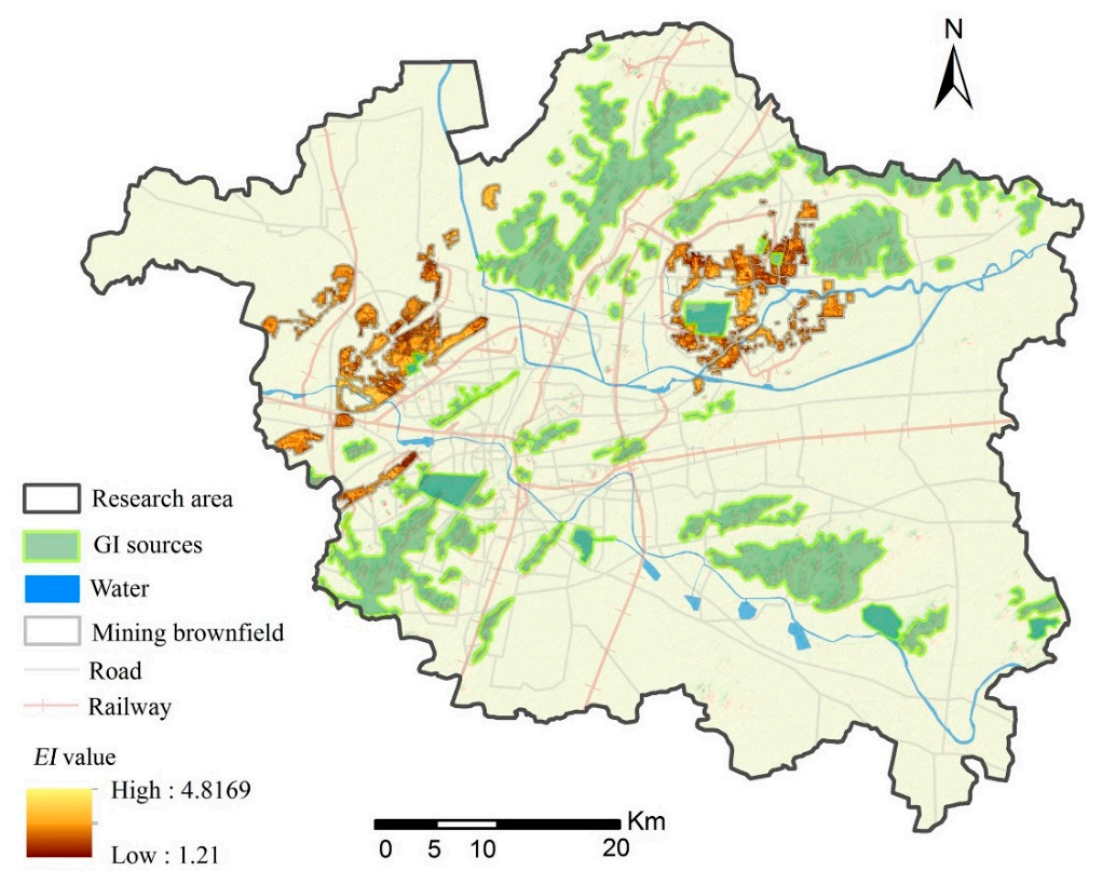

Figure 7. The EI value of coal mining brownfields.

\subsection{Patch Importance Value (dPC)}

The patch importance values of the mining brownfields in Xuzhou are between 0.00015-0.53845, but its distribution is extremely uneven (Figure 8). There are 70 brownfield patches (in total size of $0.09 \times 10^{8} \mathrm{~m}^{2}$ ) with scores below 0.025 (accounting for $47.62 \%$ of the total number of mining brownfield patches and $8.32 \%$ of the total area of mining brownfield), which have a lower effect on maintaining GI connectivity. There are 73 patches (in size of $0.82 \times 10^{8} \mathrm{~m}^{2}$ ) with scores between $0.025-0.1$ (accounting for $49.66 \%$ of the total number of brownfield patches and $75.75 \%$ of the total area), which have a medium effect on maintaining the landscape connectivity. There are only four patches with scores above 0.3 (accounting for $2.72 \%$ of the total number of mining brownfields and $15.93 \%$ of the brownfield area), which play an important role in maintaining the GI connectivity.

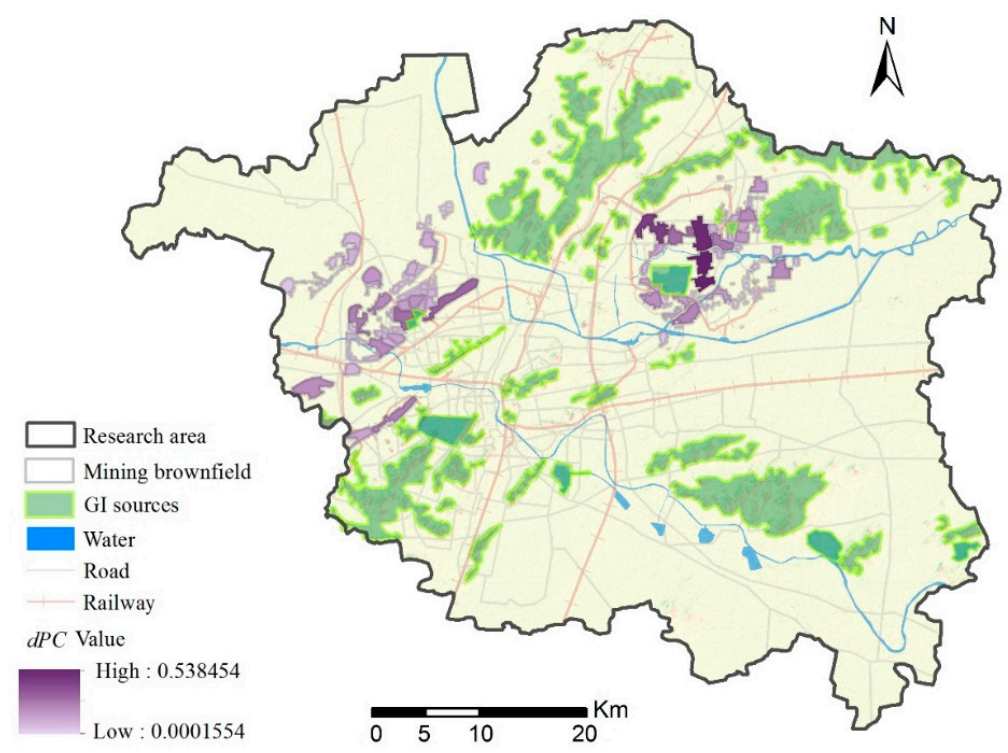

Figure 8 . The GI connectivity $(d P C)$ value of coal mining brownfields. 


\subsection{The Ecological Potential Value (Pgi)}

According to Formula (1), the Pgi values of mining brownfields were calculated based on the $E I$ and $d P C$ values. Using the natural breakpoint method, the $P g i$ values were divided into five grades (very low, low, medium, high, and very high), showing the potential of coal mining brownfield conversion to GI (Figure 9). The higher the Pgi value, the more suitable the area was to be included in the urban GI system. The total area of the mining brownfields with "very high" and "high" Pgi values was $0.56 \times 10^{8} \mathrm{~m}^{2}$, accounting for $51.35 \%$ of the total brownfield area. These were located in the eastern part of the western mining area and the center of the eastern mining area. The mining brownfields with "medium" Pgi values occupied an area of $0.22 \times 10^{8} \mathrm{~m}^{2}$, accounting for $20.18 \%$ of the total, and the brownfields with "low" and "very low" Pgi values were nearly $0.31 \times 10^{8} \mathrm{~m}^{2}$, accounting for $28.47 \%$ of the total.

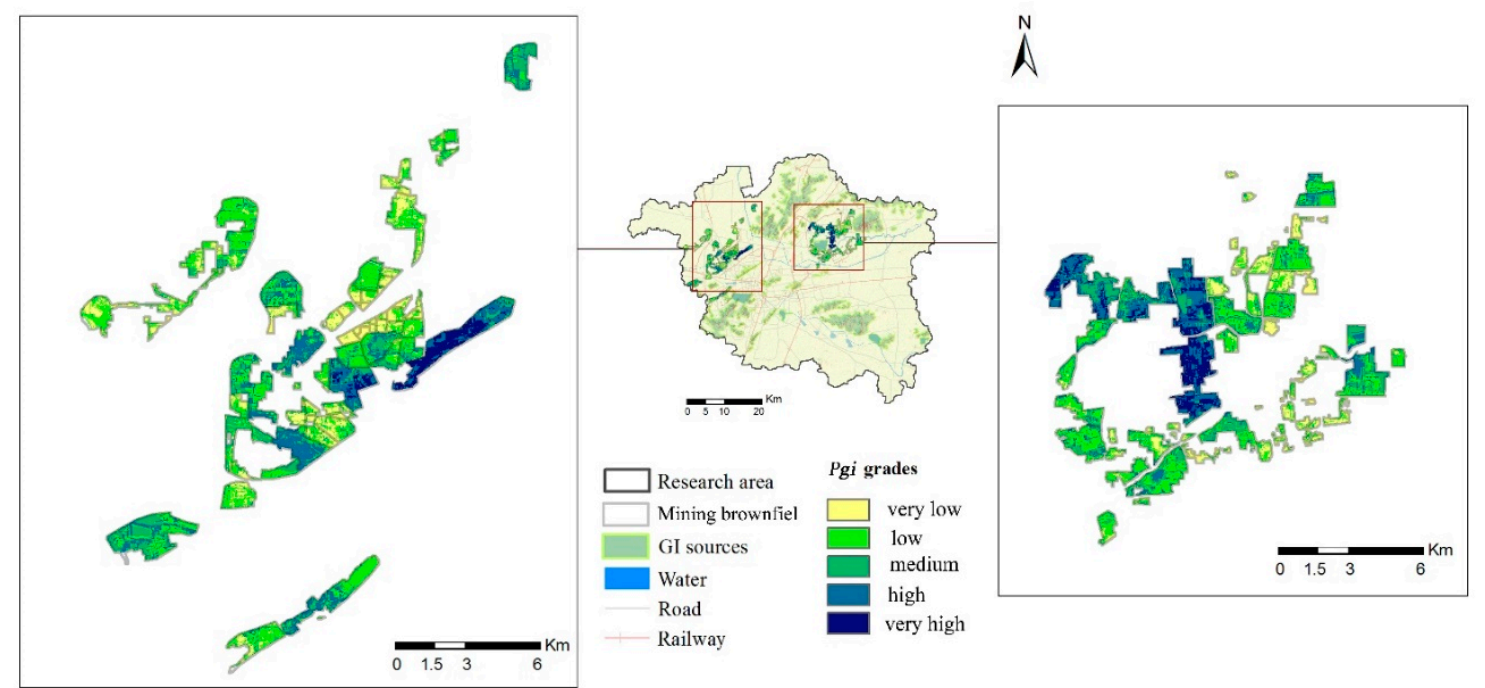

Figure 9. The grades of ecological potential of coal mining brownfields regeneration to GI.

\section{Discussion and Conclusion}

This paper proposes a quantitative method to identify the suitability of changing coal mining brownfields to GI, aiming at increasing the total GI area and strengthening the landscape connectivity. It considers not only the ecological importance on site, but also the locations of coal mining brownfields in the urban GI structure at the city level, namely the impact of "mining brownfield greening" on urban GI connectivity.

This GIS-based method allows decision makers and city planners to choose those coal mining brownfields with the greatest ecological potential, and integrate them into GI. We assumed that the mining brownfields with "very high" and "high" Pgi values can be considered for integration into the GI system. Based on the attribute extraction function and the grid turning function on the GIS platform, mining brownfields with the Pgi grades 4 and 5 were extracted, as shown in Figure 10a.

By integrating mining brownfields into the urban GI system, the structure of GI in Xuzhou presents a special wedge-shaped structure (Figure 10b), namely "one heart, four wedges, two corridors, and multiple points". "One Heart" refers to Weishan Lake Protection Area; the "Four Wedges" are the Lvliang Mountain Scenic Area, Dadong-Panan Scenic Area, Yunlong Lake Scenic Area, and Jiuli Lake Scenic Area. "Two corridors" refers to the Old Yellow River and the Beijing-Hangzhou Grand Canal as well as the greenbelt alongside them. As shown in the above figure, brownfield greening will supplement the current green space system. For example, the mining brownfield in the eastern mining area will play a role in extending the Dadongshan green wedge, and bring the greenbelt deep into the urban area from the southwest-northeast direction. Also, the greening of coal mining brownfields around Pan'an wetland parks will increase the area of GI source patches. Lastly, the 
mining brownfields in the western mining area will compensate for the lack of a large-scale green belt in the northwest of Xuzhou; and the mining brownfields along rivers will reconnect and strengthen the Old Yellow River green belt.

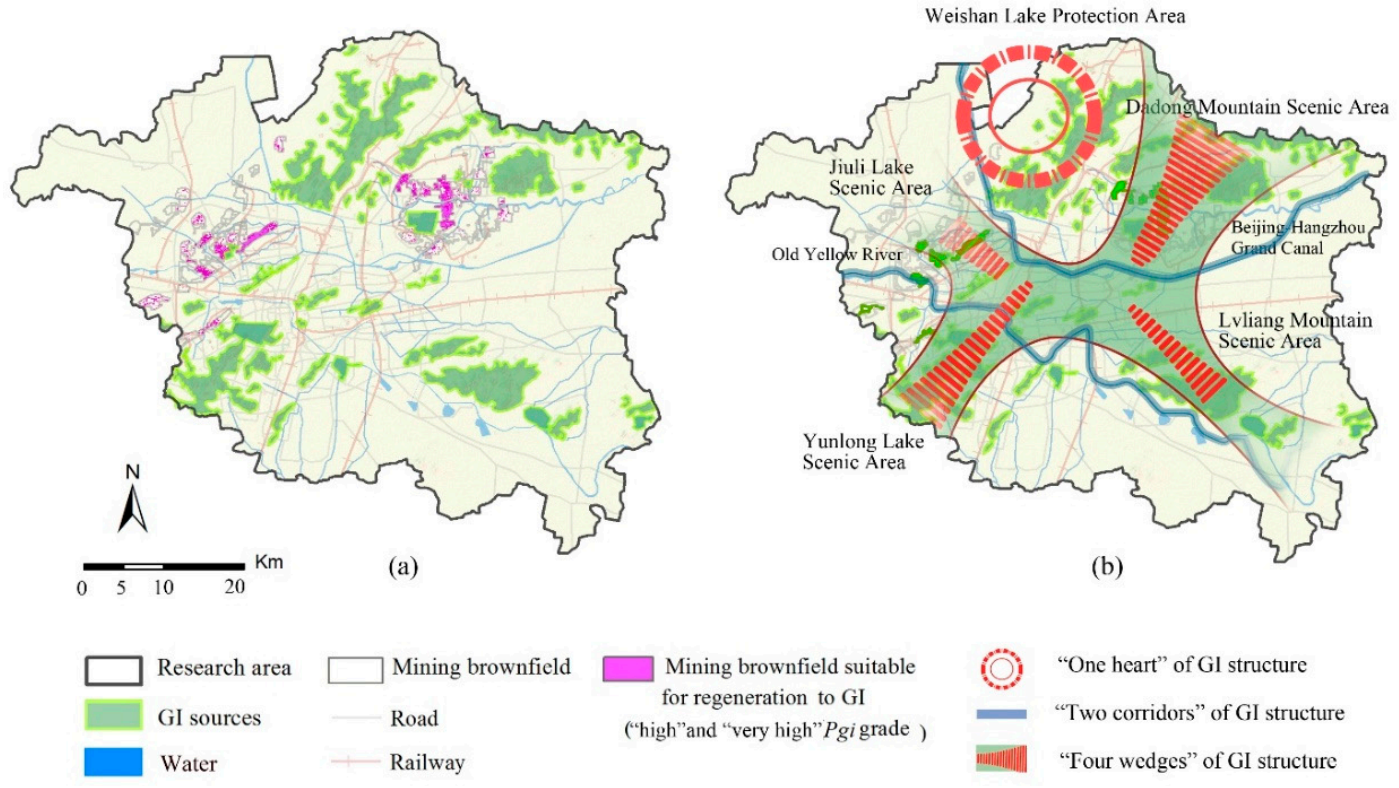

Figure 10. GI structure in Xuzhou based on coal mining brownfield greening. (a) The mining brownfields that should be integrated into GI (Pgi $\geq 4)$; (b) GI structure planning in Xuzhou.

Coal mining brownfield greening will increase the area and landscape connectivity of urban GI. In this case study, there are 147 coal mining brownfield patches in the urban area of Xuzhou. With the objective of increasing the area and connectivity of GI network, the ecological potential values of coal mining brownfield regeneration to GI were divided into five grades based on evaluation of the ecological importance and patch importance. On the premise of restoring mining brownfields to urban GI, this paper suggests the integration of $51.35 \%$ of the mining brownfields into the urban GI system, which have the Pgi grades of high or very high. From the perspective of ecological importance, more than half of the mining brownfield is suitable to be regenerated to GI, as it has a greater potential to increase urban biodiversity. Regarding the effect on maintaining the stability of the GI network, most of the mining brownfields have a small effect, and only four mining brownfields hold a prominent role. Therefore, the ecological potential of each mining brownfield is significantly different.

This approach is a new attempt to improve the sustainable development of mining cities from "economic priority" to "ecological priority". The approach focused on the ecological potential of coal mining brownfield regeneration to GI, which can provide an ecological basis for land-use decision making in brownfield regeneration and greenspace construction. However, it has limitations: the extent of the current research is not sufficient to consider the subsidence depth and damage degree, the plant and animal species in the brownfield, as well as the various economic and social factors. Additionally, the research is focused on coal mining brownfield, but did not consider the other types of brownfield, because the area of the coal mining brownfield accounts for a large proportion of the total brownfield in Xuzhou. Other factors may be necessarily considered in future research, such as ecosystem services, community residents' wishes, and the costs and benefits of converting to GI. Furthermore, the evaluation method should be adapted according to the different characteristics of other types of brownfield. The subsidence of coal mining brownfield usually is a long-term process with dynamic change. Therefore, the subsidence prediction of coal mining brownfield should also be considered, and multi-period studies are needed. 
Author Contributions: All the authors contributed equally to this work. S.F. and J.C. conceived, conceptualized, and designed the research plan; W.H. is responsible for the research methodology, software provision and key technology solutions. S.F. wrote the original draft, which was revised by W.H. and J.C. All the authors read and approved the final manuscript.

Funding: This research was funded by the National Natural Science Foundation of China (No. 41671524 No. 41701213, and No. 51808543) and the Doctoral Special Research Fund of Jiangsu Collaborative Innovation Center for Building Energy Efficiency and Construction Technology (No. SJXTBS1718).

Conflicts of Interest: The authors declare no conflict of interest.

\section{References}

1. Hu, Z.Q.; Fu, Y.H.; Xiao, W.; Zhao, Y.L.; Wei, T.T. Ecological restoration plan for abandoned underground coal mine site in Eastern China. Int. J. Min. Reclam. Environ. 2015, 29, 316-330. [CrossRef]

2. Feng, Y.X.; Li, G.W. Planning and design theory of mining brownfield based on landscape urbanism. Urban Plan. J. 2013, 208, 93-98. [CrossRef]

3. Zhou, M.; Chen, H. Preliminary study on spatial models, problems and planning strategies of resource-based cities. Mod. Urban. Res. 2011, 7, 55-58. [CrossRef]

4. Yang, Z.B.; Bian, Z.F. Study on the degradation mechanism of ecosystem in mining areas of Eastern China. Energy Environ. Prot. 2000, 14, 44-47. [CrossRef]

5. Yang, G.H.; Hu, Z.Q.; Zhao, Y.L.; Yang, Y.Q.; Yu, Y. Study on reclamation and control of coal mining subsidence land with high groundwater level. Coal Eng. 2014, 46, 91-95. [CrossRef]

6. Ye, D.J.; Zhan, X.M. Study on renovation and ecological restoration of coal mining subsidence area: A case study of conceptual planning of Pan'an Lake Wetland Park, Xuzhou. China Water Transp. 2011, 11, 242-243. [CrossRef]

7. Qu, J.F.; Li, G.; Zhang, S.L. Reclamation and wetland ecological protection in high-phreatic-water level mining subsidence area: A case study of Jiuli, Xuzhou. Soil Water Conserv. China 2014, 1, 37-39. [CrossRef]

8. Zhao, Y.H.; Zhao, H. Analysis of spatial expansion characteristics of water area in high-phreatic-water level mining area: A case study of Peibei mining area in Xuzhou. China Min. Ind. 2017, 26, 95-98. [CrossRef]

9. Fu, Y.H.; Hu, Z.Q.; Xiao, W.; Rong, Y.; Long, J.H. Ecological restoration of coal subsidence wetland in high diving mining area. Wetl. Sci. 2016, 14, 671-676. [CrossRef]

10. Xiao, W.; Chen, J.L.; Hu, Z.Q.; Chen, Y.C.; Zhang, J.Y. Feasibility analysis and practice of constructing plain reservoir in coal mining subsidence area with high groundwater level. Coal Sci. Technol. 2017, 45, 184-189. [CrossRef]

11. Loures, L.; Panagopoulos, T. Reclamation of derelict industrial land in Portugal: Greening is not enough. Int. J. Sustain. Dev. Plan. 2010, 5, 343-350. [CrossRef]

12. Sousa, D.; Christopher, A. The greening of brownfields in American cities. J. Environ. Plan. Manag. 2004, 47, 579-600. [CrossRef]

13. Dorsey, J.W. Brownfields and Greenfields: The Intersection of Sustainable Development and Environmental Stewardship. Environ. Pract. 2003, 5, 69-76. [CrossRef]

14. Sousa, D.; Christopher, A. Unearthing the benefits of brownfield to green space projects: An examination of project use and quality of life impacts. Local Environ. 2006, 11, 577-600. [CrossRef]

15. Doick, K.J.; Sellers, G.; Castán Broto, V.; Silverthorne, T. Understanding success in the context of brownfield greening projects: The requirement for outcome evaluation in urban greenspace success assessment. Urban For. Urban Green. 2009, 8, 163-178. [CrossRef]

16. Atkinson, G.; Doick, K.J.; Burningham, K.; France, C. Brownfield regeneration to greenspace: Delivery of project objectives for social and environmental gain. Urban For. Urban Green. 2014, 13, 586-594. [CrossRef]

17. Pediaditi, K.; Doick, K.J.; Moffat, A.J. Monitoring and evaluation practice for brownfield, regeneration to greenspace initiatives: A meta-evaluation of assessment and monitoring tools. Landsc. Urban Plan. 2010, 97, 22-36. [CrossRef]

18. Sousa, C.A.D. Turning brownfields into green space in the city of Toronto. Landsc. Urban Plan. 2003, 62, 181-198. [CrossRef]

19. Siikamäki, J.; Wernstedt, K. Turning brownfields into greenspaces: Examining incentives and barriers to revitalization. J. Health Polit. Policy Law 2008, 33, 559-593. [CrossRef] [PubMed] 
20. Altherr, W.; Blumer, D.; Oldvorp, H.; Nagel, P. How do stakeholders and legislation influence the allocation of green space on brownfield redevelopment projects? Five case studies from Switzerland, Germany and the UK. Bus. Strategy Environ. 2010, 16, 512-522. [CrossRef]

21. Mathey, J.; Rößler, S.; Banse, J.; Lehmann, I.; Bräuer, A. Brownfields as an element of green infrastructure for implementing ecosystem services into urban areas. J. Urban Plan. Dev. 2015, 141, A4015001. [CrossRef]

22. Gill, S.E.; Handley, J.F.; Ennos, A.R.; Pauleit, S. Adapting cities for climate change: The role of the green infrastructure. Built Environ. 2007, 33, 115-133. [CrossRef]

23. Feng, S.S.; Chang, J. Mining brownfield: Opportunity to improve green infrastructure. Chin. Landsc. Archit. 2017, 33, 24-28.

24. Wirth, P.; Chang, J.; Syrbe, R.U.; Wende, W.; Hu, T. Green infrastructure: A planning concept for the urban transformation of former coal-mining cities. Int. J. Coal Sci. Technol. 2018, 5, 1-14. [CrossRef]

25. Lin, Z.R.; Chang, J.; Wang, W. Ecological restoration planning of coal mining subsidence area in Xuzhou based on urban-rural coordination. Mod. Urban Res. 2009, 10, 91-95. [CrossRef]

26. Sino-German Research Center of CUMT. Ecological Restoration Planning of Coal Mining Subsidence Area in Xuzhou; Research Report; CUMT: Xuzhou, China, 2012.

27. Luo, P.J.; Lu, W.X.; Ren, L.Y. Re-use planning methods of the mining subsidence area based on landscape ecology: A case study of Jiuli area, Xuzhou. Chin. Landsc. Archit. 2011, 27, 96-100. [CrossRef]

28. Yang, R.Q.; Wang, Q.Q.; Xu, D.L. Investigation of the plant diversity in Pan'an Lake Wetland Park. J. Northwest For. Univ. 2018, 33, 285-289. [CrossRef]

29. Ma, Y.H.; Zhang, Y.J. Wetland ecotourism development strategy for coal mining subsidence wetland-A case study of Jiuli Lake in Xuzhou city. Wetl. Sci. Manag. 2013, 2, 21-24. [CrossRef]

30. Chang, J.; Hu, T.H.; Liu, X.X.; Ren, X.G. Construction of green infrastructure in coal-resource based city: A case study in Xuzhou urban area. Int. J. Coal Sci. Technol. 2018, 5, 92-104. [CrossRef]

31. Qiu, Y.; Chang, Q.; Wang, J.A. MSPA-based planning of urban Green Infrastructure network-a case of Shenzhen. Chin. Landsc. Archit. 2013, 5, 104-108.

32. Xie, H.L.; Li, X.B. Spatial assessment and zoning regulations of ecological importance based on GIS for rural habitation in Changgang Town, Xinguo county. Acta Ecol. Sin. 2011, 31, 230-238. [CrossRef]

33. Zhou, B.Z.; Yang, H.; Bao, H.S.; Zhao, Q.G.; Zhou, S.L. PSR model and its application in the evaluation of sustainable land-use in the region. J. Nat. Resour. 2002, 17, 541-548. [CrossRef]

34. Xie, G.D.; Zhen, L.; Lu, C.X.; Xiao, Y.; Chen, C. An expert knowledge-based approach to ecosystem service value. J. Nat. Resour. 2008, 23, 911-919. [CrossRef]

35. Yang, F.; He, Y.; Zhao, Z.J. An evaluation method of nimby effect of urban municipal infrastructure. J. Peking Univ. (Nat. Sci. Ed.) 2017, 53, 518-524. [CrossRef]

36. Shen, S.G.; Wang, H.; Jia, D.P.; Gu, K. Land suitability evaluation methods for urban green space system planning based on GIS in Changzhou city. J. Nanjing For. Univ. (Nat. Sci.) 2009, 33, 72-76. [CrossRef]

37. Lu, T.W.; Song, K.; Yang, X.; Wang, X.J. Research of urban land-use planning based on ecology suitability evaluation: A case study of ecological subzone in Southeast Hangzhou. J. Fudan Univ. (Nat. Sci.) 2011, 50, 245-251. [CrossRef]

38. He, D.; Jin, F.J.; Zhou, J. Urban construction land suitability evaluation in resource-based cities: Taking the Grand Canal Ecologic and Economic Area as an example. Geogr. Res. 2011, 30, 655-666. [CrossRef]

39. Chen, Y.F.; Du, P.F.; Zhen, X.J.; Lin, J. Evaluation on ecological applicability of land construction in Nanning city based on GIS. J. Tsinghua Univ. (Sci. Technol.) 2006, 46, 801-804. [CrossRef]

40. Wu, J.S.; Zhang, L.Q.; Peng, J.; Feng, Z.; Liu, H.M.; He, Z.B. The integrated recognition of the source area of the urban ecological security pattern in Shenzhen. Acta Ecol. Sin. 2013, 33, 4125-4133. [CrossRef]

41. Xiong, C.N.; Wei, H.; Lan, M.J. Analysis of connectivity on greenland landscape in metropolitan region of Chongqing City. Acta Ecol. Sin. 2008, 28, 2237-2244. [CrossRef]

(C) 2019 by the authors. Licensee MDPI, Basel, Switzerland. This article is an open access article distributed under the terms and conditions of the Creative Commons Attribution (CC BY) license (http://creativecommons.org/licenses/by/4.0/). 